\title{
ALQURAN DAN BAHASA SUNDA POPULER: RESPONS GENERASI MILENIAL TERHADAP TERJEMAHAN ALQURAN BAHASA SUNDA
}

\author{
JAJANG A.ROHMANA \\ UIN Sunan Gunung Djati Bandung \\ Email: jajangarohmana@uinsgd.ac.id
}

\begin{abstract}
The article focuses on the response of millennial generation to the Sundanese translation of the Qur'ān, Al-Qur'an Miwah Tarjamahna dina Basa Sunda(2002), published by the Provincial Government and the Regional Office of the Ministry of Religious Affairs of West Java. The research subjects are Sundanese students at Qur'ānic Studies and Tafsir Department (IAT), Faculty of Ushuluddin, UIN Sunan Gunung Djati Bandung who was born after 1995. This case study research uses the assignment techniques for students to read, respond and propose Sundanese words in the translation. This study confirms the importance of Qur'ānic translatorto consider the needs of the Sundanese millennial generation who live in the digital lifestyles. In the context of translation of Q.Al-fatih\}ah[1]:1-7 and Q.AlBaqarah[2]:1-286, the majority of the students do not understand the characteristics of Sundanese in the translation, such as the use of language levels, idiomatic expressions and old Sundanese vocabulary. They then propose alternative translations that are more popular, such as simple language levels, loan words and more popularSundanese vocabulary. It is a response that shows the dynamics of the use of Sundanese language among the young generation and its gap between the reader and the Qur'ānic translation which produced by the local government in Indonesia.
\end{abstract}

Keywords:

the Qur'ān, translation, Sundanese, students, millenial generation.

\begin{abstract}
Abstrak
Kajian ini memfokuskan pada respons generasi milenial Sunda terhadap karya terjemah Alquran bahasa Sunda, $A l$ Qur'an Miwah Tarjamahna dina Basa Sunda, terbitan Pemda Provinsidan Kanwil Depag Jawa Barat tahun 2002. Subjek penelitiannya adalah mahasiswa Sunda pada Prodi IAT Fakultas Ushuluddin UIN Sunan Gunung Djati Bandung yang lahir sesudah tahun 1995. Penelitian dilakukan dengan teknik penugasan untuk membaca, memberi tanggapan dan mengusulkan kosakata Sunda dalam terjemahan. Melalui analisis teori terjemahan,kajian ini menegaskan pentingnya penerjemah Alquran untuk mempertimbangkan kebutuhan generasi milenial Sunda yang hidup dalam gaya hidup digital. Dalam kasus terjemahan surah al-fa>tih\}ah dan Al-Baqarah (Juz 1-3) misalnya, mayoritas mahasiswa kurang paham dengankarakteristik bahasa Sunda dalam terjemahan tersebut, terutama terkait dengan penggunaan tingkatan bahasa, ungkapan idiomatik dankosakatalama. Mereka kemudian mengusulkan alternatif terjemahan yang lebih populer, seperti tingkatan bahasa yang sederhana, kosakataserapan dari bahasa lain dankosakatayang lebih kekinian. Sebuah tanggapan yang tidak saja menunjukkan dinamika penggunaan bahasa Sunda di kalangan generasi muda, tetapi juga adanya kesenjangan antara pembaca dengan teks terjemahan Alquran yang diproduksi oleh pemerintah daerah di Indonesia.
\end{abstract}

Keywords :

Alquran. terjemah, bahasa Sunda, mahasiswa, generasi milenial

\section{A. PENDAHULUAN}

Terjemahan Alquran bahasa Sunda sudah banyak disusun. Penyusunnya adalah orang Sunda, etnis terbesar setelah Jawa, tetapi merupakan penganut Muslim terbesar di Indonesia ${ }^{1}$.Hasil kajian sebelumnya menunjukkan bahwa terdapat sekitar lima

\footnotetext{
${ }^{1}$ Aris. Suryadinata, Leo., Arifin, Evi Nurvidya., dan Ananta, Indonesia's Population: Ethnicity and Religion in a Changing Political Landscape (Singapore: Institute of Southeast Asian Studies, 2003), 109.
}

belaspublikasi terjemah Alquran dalam bahasa Sunda yang terbit sejak era pra-kemerdekaan. Jenis terjemahannya menunjukkan keragaman, baik dari sisi aksara, sumber terjemahan, bentuk, metode, latar penerjemah, cakupan, maupun dialek terjemahannya ${ }^{2}$.Dari sekian banyak terjemahantersebut, PemdaProvinsi dan Kanwil Departemen Agama (sekarang Kementerian Agama) Jawa Barat sudah dua kali menyusun terjemahan Alquran bahasa

2 Jajang A.Rohmana, Sejarah Tafsir Alquran Di Tatar Sunda (Bandung: Mujahid Press, 2017), 7-8. 
Sunda, yakni Tarjamah Al-Qur'äan Bahasa Sunda (1974/1975) dan Al-Qur'an Miwah Tarjamahna dina Basa Sunda (2002) ${ }^{3}$.

Namun, terjemahan versi pemerintah lokal tersebut boleh jadi disusun dan dikonsumsi oleh "generasi lama"yang lahir dan tumbuh dalam alam teknologi manual, bukan digital. Penggunaan bahasa Sundanya juga cenderung didominasi bahasa lama (buhun). Ini berbeda dengan generasi yang lahir sesudah tahun 1990-an (25 tahun terakhir) atau dikenal dengan generasi milenial ${ }^{4}$. Merekalahir dan tumbuh di tengah frekuensi penggunaan bahasa Sunda yang semakin memudar. Studi Sobarna dkk. misalnya, sudah membuktikan penurunan penggunaan bahasa Sunda tersebut sejak lama setidaknya di lingkungan remaja Kota Bandung. Salah satu penyebabnya adalah karenapengaruh bahasa lainnya. Pola pikir penggunaannya diawali dari bahasa Indonesia lalu diterjemahkan ke bahasa Sunda, sehingga sistem gramatika bahasa Indonesiasemakin dominan ${ }^{5}$.Dominasi tersebut juga tampak di berbagai media massa ${ }^{6}$.Akibatnya, bahasa Sunda semakin jarang digunakan, karena didesak keperluan komunikasi dengan

\footnotetext{
3 Pemda Provinsi dan Kanwil Depag Jawa Barat, Tarjamah Al-Quräan Basa Sunda, Dikaluarkeun Ku Proyek Penerbitan Al-Qur'än Bahasa Sunda Jawa Barat (Bandung: Pemda Provinsi dan Kanwil Depag Jawa Barat, n.d.); Pemda Provinsi dan Kanwil Depag Jawa Barat, Al-Qur'an Miwah Tarjamahna Dina Basa Sunda, Bandung: Kerjasama Pemda Provinsi Jawa Barat, MUI, LPTQ, Kanwil Depag Jawa Barat. (Bandung: Pemda Provinsi dan Kanwil Depag Jawa Barat, 2002).

${ }^{4}$ Noorhaidi Hassan, "Menuju Islamisme Populer," Dalam Noorhaidi Hassan Ed., Literatur Keislaman Generasi Milenial: Transmisi, Apropriasi, Dan Kontestasi (Yogyakarta: Pascasarjana UIN Sunan Kalijaga Press, 2018), 10.

${ }^{5}$ Cece Sobarna, "Bahasa Sunda Sudah Di Ambang Pintu Kematiankah?," Jurnal Makara, Sosial Humaniora 11, no. 1 (n.d.): 78-79.

${ }^{6}$ Tim Pelaksana, Kosa Kata Bahasa Sunda Dalam Media Massa (Jakarta: Pusat Pembinaan dan Pengembangan Bahasa Departemen Pendidikan dan Kebudayaan, 1984), 1.
}

pengguna bahasa non-Sunda ${ }^{7}$.Hal ini tidak hanya berdampak pada penggunaan bahasanyamenjadi simpel, populer dan dipenuhi $\operatorname{serapan}^{8}$,tetapi juga membuat literatur bahasa Sunda lama menjadi kurangbisa dipahami, termasuk di dalamnya literatur keagamaan seperti terjemahan Alquran bahasa Sunda.Oleh karena itu, untuk mengetahui pemahamangenerasi milenial Sunda tentang terjemahan Alquran tersebut diperlukan kajian tentang tanggapan mereka terhadapliteraturterjemahan sebelumnya, yaitu Al-Qur'an Miwah Tarjamahna (2002).

Kajian ini penting mengingat sebelumnya hampir tidak ada terjemahan Alquran bahasa Sunda yang mempertimbangkan kebutuhan generasi milenial Sunda sebagai pewaris penjaga kelestarian bahasa Sunda yang semakin terancam ${ }^{9}$.Padahal mereka sangat membutuhkan terjemahan Sunda yang sesuai dengan kebutuhan zamannya. Selain itu, posisi generasi milenial yang sangat tergantung pada budaya digital melalui smartphone dengan pola konsumsi dan gaya hidup instan ${ }^{10}$,sangat rentan terhadap berbagai pengaruh, termasuk paham dan ajaran radikal yang bersumber dari website, media sosial, pengajaran agama, literatur keagamaan dan organisasi siswa (OSIS)sebagaimana ditunjukkan dalam hasil penelitian Convey Indonesia ${ }^{11}$.Karenanya, terjemahan Alquran bahasa Sunda yang disusun berdasarkan paham moderat, baik dalam terjemahan ayat-ayat teologi, fiqih,

\footnotetext{
${ }^{7}$ Sobarna, "Bahasa Sunda Sudah Di Ambang Pintu Kematiankah?," 13.

${ }^{8}$ T. Fatimah Djajasudarma, "Kecap Anteuran Basa Sunda: Satu Kajian Semantik Dan Struktur" (Universitas Indonesia, n.d.), 3.

${ }^{9}$ Ajip Rosidi, "Mengapa Bahasa Sunda Bisa Mati?," Cupumanik 11, Juni (2004): 11.

10 Hassan, “Menuju Islamisme Populer," Dalam Noorhaidi Hassan Ed., Literatur Keislaman Generasi Milenial: Transmisi, Apropriasi, Dan Kontestasi, 11.

11 Tim Penyusun., Ringkasan Eksekutif Program Convey Indonesia (Jakarta: Enhancing the Role of Religious Education in Countering Violent Extremism in Indonesia, Pusat Pengkajian Islam dan Masyarakat (PPIM), UIN Syarif Hidayatullah Jakarta, 2018).
} 
sosial, politik, maupun ekonomi, disertai dengan bahasa yang mudah dipahami oleh mereka sangat dibutuhkan. Dengan demikian, untuk memenuhi kebutuhan itu, sebagai langkah awal diperlukan terlebih dulu kajian tentang pandangan generasi milenial terhadap terjemahan Alquran bahasa Sunda sebelumnya.

Sejumlah kajian terdahulu tentang terjemahan Alquran bahasa Indonesia maupun bahasa daerah belum banyak yang menyentuh masalah terjemahan bagi generasi milenial. Umumnya para sarjana membahas terjemahan Alquran yang terkait dengan politik pemerintah era Orde Baru, kepentingan teologi yang dianut mayoritas,koreksi atas terjemahan versi pemerintah, pelarangan terjemahan dan polemik terjemahan puitis di Indonesia $^{12}$. Kajian Zimmer dan Rohmana sebelumnya juga lebih banyak mengkaji tentang tafsir Alquran bahasa Sunda dan terjemahan puitis Alquran bahasa Sunda $^{13}$.Sedikitnya minat para sarjana untuk

12 Moch. Nur.Ichwan, Negara, Kitab Suci, Dan Politik: Terjemah Resmi Alquran Di Indonesia, Dalam Sadur, Sejarah Terjemahan Di Indonesia Dan Malaysia, Ed. Henri Chambert-Loir, (Jakarta: KPGEFEO-Pusat Bahasa Unpad, 2009); Johanna Pink, "Literal Meaning or Correct 'Aqīda? The Reflection of Theological Controversy in Indonesian Qur'an Translations," Journal of Qur'anic Studies 17, no. 3 (2015): 100-120; Ismail Lubis, Falsifikasi Terjemahan Alquran Departemen Agama, 1990th ed. (Yogyakarta: Tiara Wacana, 2001); Munirul Ikhwan, "Fī Tahaddī AlDawlah: Al-Tarjamah Al-Tafsīriyyah Fī Muwäjahah Al-Khițäb Al-Dīn̄̄ Al-Rasmī Li Al-Dawlah AlIndunīsiyyah," Journal of Qur'anic Studies 17, no. 3 (2015): 121-157; Moh.Zuhri, Terjemah Puitis AlQur'an, Kritik Ilmu Ma'ani Terhadap Al-Qur'anul Karim Bacaan Mulia Karya H.B. Jassin (Yogyakarta: Lintang-PPs IAIN Walisongo, 2012).

13 Benjamin G.Zimmer, "Al-'Arabiyyah and Basa Sunda: Ideologies of Tranlation and Interpretation among the Muslims of West Java," Studia Islamika, Indonesian Journal for Islamic Studies 7, no. 3 (2000): 31-65.A.Rohmana, Sejarah Tafsir Alquran Di Tatar Sunda.Jajang A.Rohmana, "Memahami Alquran Dengan Kearifan Lokal: Nuansa Budaya Sunda Dalam Tafsir Alquran Berbahasa Sunda," Journal of Qur'än and Hadìth Studies 3, no. 1 (2014): 79-99.Jajang mengkaji masalah terjemahan bahasa lokal bagi kalangan generasi milenial, selain karena isu generasi milenial relatif masih baru, juga keterbatasan terjemahan Sunda untuk bisa diakses oleh sarjana non-Sunda.Karenanya, kajian tentang pandangan generasi milenial Sunda terhadap terjemahan Alquran sangat penting dilakukan. Kajian ini diharapkan bisa menjadi masukan bagi penyusun terjemahan Alquran bahasa Sunda untuk mempertimbangkan kebutuhan generasi milenial. Kajian diharapkan memiliki kontribusi bagi pengembangan kajian terjemahan Alquran di Nusantara. Sebuah upaya penguatan kajian lokal dalam studi Alquran dan terjemahan sebagai bagian dari kekayaan khazanah keislaman di Indonesia.

Kajian ini merupakan studi kasus tanggapan generasi milenial Sunda tehadap terjemahan Alquran bahasa Sunda. Pengumpulan data dilakukan dengan menggunakan teknik penugasan pada mahasiswa Sunda angkatan 2015 (semester VI) pada Prodi Ilmu Alquran dan Tafsir (IAT) Fakultas Ushuluddin UIN Sunan Gunung Djati Bandung antara bulan Februari-Mei 2018. Jumlahnya sekitar 177 mahasiswadaritotal 203 mahasiswa yang terbagi ke dalam lima kelas (masing-masing enam juz'). Mahasiswa yang dipilih adalah mahasiswaSunda, yakni mereka yang mengaku dirinya sebagai orang Sunda dan diakui oleh orang lain sebagai orang Sunda ${ }^{14}$. Pilihan juga didasarkan pada kemampuan dalam memahami teks terjemahan Sundadan statusnya sebagai mahasiswa Prodi IAT yang mendapatkan Mata Kuliah Tafsir Sunda.

\footnotetext{
A.Rohmana, "Metrical Verse as a Rule of Qur'anic Translation: Some Reflections on R.A.A. Wiranatakoesoema'sSoerat Al-Baqarah(1888-1965)," Al-Jami'ah Journal of Islamic Studies 53, no. 2 (2015): 439-67.

14 Suwarsih Warnaen Dkk, Pandangan Hidup Orang Sunda Seperti Tercermin Dalam Tradisi Lisan Dan Sastra Sunda (Bandung: Bagian Proyek Penelitian dan Pengkajian Kebudayaan Sunda (Sundanologi) Dirjen Kebudayaan Depdikbud Bandung, 1987), 1.
} 
Penugasan yang diberikan pada mereka adalah memberikan tanggapan berupa komentar atasterjemahan dalam al-Qur'an Miwah Tarjamahna (2002). Komentar yang diminta adalah tentang kata atau kalimat yang kurang dipahami dan usulan kosakataalternatif dari mereka.Peneliti juga mewawancaraibeberapa mahasiswa IAT untuk mengkonfirmasi kekurangpahamannya terhadap kosakata Sunda

\section{B. PEMBAHASAN}

\section{Tentang Al-Qur'an Miwah Tarjamahna}

Terjemahan Alquran bahasa Sunda ini merupakan terjemahan resmi kedua yang diterbitkan oleh Pemerintah Daerah Provinsi (disingkat Pemda Provinsi) dan Kantor Wilayah Departemen Agama (disingkat Kanwil Depag) JawaBarat. Sebelumnya, Pemda Provinsi sudah menerbitkan Tarjamah Alquran Bahasa Sundadalam proyek Pembangunan Lima Tahun (PELITA) 19741979. Al-Qur'an Miwah Tarjamahnayang terbit tahun 2002 ini termasuk cukup eksklusif dalam tampilannya, karena menggunakan MushafSundawi. Sebuah jenis mushaf yang disusun 1995-2000 dan dirancang khusus dengan menggabungkan seni kaligrafi yang berbasis kepada Alquran Standar Depag dengan kekayaan ragam hias dan budaya Jawa Barat $^{15}$.

Penyusunan Al-Qur'an Miwah Tarjamahna dilaksanakeun oleh Pemda Provinsi Jawa Barat melalui SK Gubernur Jawa Barat, Danny Setiawan. Pelaksananya adalah Lembaga Pengembangan Tilawatil Quran (LPTQ) Provinsi Jawa Barat dengan melibatkan Dewan Panasehat dari para tokoh MUI Jabar, ormas Islam, tim ahli naskah, para sarjana dan pakar Alquran dari beberapa perguruan tinggi Islamdan melibatkan para ahli bahasa, sejarah, budaya, dan sastra Sunda.

15 Tim Pelaksana Penulisan Alquran Mushaf Sundawi, Alquran Al-Karim Mushaf Sundawi (Bandung: Tim Pelaksana Penulisan Alquran Mushaf Sundawi, 1997), 3.
Perkawinan antara seni kaligrafi dan ragam hias tersebut kemudian menjelma dalamkarya terjemahan ini. Sebuah karya yang diakui merupakan buktieratnya orang Sunda dengan Al-Qur'an. Dari sisirujukan, terjemahan ini merujuk pada proyek terjemahanbahasa Sunda sebelumnya dan Alquran dan terjemahannya berbahasa Indonesia yang diterbitkan oleh Yayasan Penyelenggara Penterjemah/Pentafsir Al-Qur'an, Depag RI tahun 1989/1990. Terjemahan ini dicetak oleh pemerintah Saudi Arabia dan dibagikan pada seluruh jemaah haji sehingga dikenal dengan edisi Saudi Arabia $(1990)^{16}$. Salah satu ciri menonjolalQur'an Miwah Tarjamahna adalah beberapa penyelasaran bahasa Sunda yang lebihhalus. Meski demikian, beberapa kekeliruan masih didapatkan menggunakan bahasa Indonesia dan penjelasan tentang ayat sajdah yang tidak dirinci secara jelas tempatnyasehingga sangat menyulitkan bagi orang awam ${ }^{17}$.

\section{Karakteristik Bahasa Sunda dalam Al- Qur'an Miwah Tarjamahna}

Karakteristik ini merupakan bentuk kekhasan bahasa Sunda yang membedakan dengan bahasa lainnya yang seringkali kurang dipahami oleh generasi muda sekarang. Ini juga diyakini sebagai "keunggulan" bahasa Sunda dibanding bahasa lain, terutama bahasa Indonesia. Karakteristik bahasa ini nanti akan dijadikan dasar untuk mengukur tanggapan generasi milenial Sunda itu di bagian berikutnya. Terdapat sedikitnya tiga karakteristik bahasa Sunda dalam Al-Qur'an Miwah Tarjamahna, yaitu tingkatan bahasa, ungkapan idiomatik dan ragam kosakata Sunda.

\footnotetext{
${ }^{16}$ Raja Kerajaan Saudi Arabia Khädim al Haramain asy Syarīfain (Pelayan kedua Tanah Suci) Fahd ibn 'Abd al 'Az̄̄z Al Sa'ūd, Alquran Dan Terjemahnya (Saudi Arabia: hädim al Haramain asy Syarīfain (Pelayan kedua Tanah Suci) Fahd ibn 'Abd al 'Azīz Al Sa’ūd, Raja Kerajaan Arab Saudi, 1990).

17 Usep Romli, "Tarjamah Quran Basa Sunda Ti Jaman Ka Jaman," in Konferensi Internasional Budaya Sunda II, Gedung Merdeka, 19-22 Desember, 2011, 34.
} 
Pertama, tingkatanatau tatakrama bahasa (undak usuk basa, speech levels). Ia merupakan sistem tingkatan tutur dalam bahasa Sunda menyangkut perbedaanperbedaan dalam hal usia, kedudukan, pangkat, tingkat keakraban serta situasi di antara yang disapa dan yang menyapa, atau antara pembicara, lawan bicara, dan yang dibicarakan. ${ }^{18}$ Dalam bahasa Sunda, sejak Kongres Basa Sunda tahun 1988 penggunaan tata krama bahasatidak lagi dimaksudkan sebagai pembedaan status sosial, tetapi menjadi alat untuk saling menghargai dan menghormati. Kini umumnya digunakan dua ketegori besar ragam bahasa: bahasa hormat (halus) dan kurang hormat (loma/kasar), untuk diri sendiri maupun orang lain. ${ }^{19}$

Al-Qur'an Miwah Tarjamahna menggunakan tata krama bahasa dengan beragam penggunaan, baik bahasa hormat maupun kurang hormat. Penerjemah berupaya menginterpretasikan bahasa Alquran yang cenderung "egaliter" untuk disesuaikan dengan latar budaya Sunda. Penggunaan tata krama bahasa misalnya, tampak pada terjemahanQ.S. Al-Naml[27]: 20-22:

\footnotetext{
${ }^{18}$ Undak usuk basa (undak = tahap, usuk = kayu yang biasanya digunakan sebagai penyangga atap rumah). Lihat Ajip Rosidi, "Ngabina jeung Ngamekarkeun Kabudayaan Sunda", dalam Ajip Rosidi, Ngabina Jeung Ngamekarkeun Kabudayaan Sunda”, Dalam Ajip Rosidi Dkk., Polémik Undak Usuk Basa Sunda (Bandung: PT. Mangle Panglipur, 1987), 19-24.Edmund A. n.d. Anderson, "Speech Levels: The Case of Sundanese," Pragmatics International Pragmatics Association 3, no. 2 (n.d.): 107.

19 Terdapat enam bentuk dalam kedua ragam bahasa ini, yaitu basa kasar, basa sedeng, basa lemes, basa lemes pisan, basa kasar pisan, dan basa panengah. Budi Rahayu Tamsyah, Kamus Undak Usuk Basa Sunda (Bandung: Geger Sunten, 2006), 9; Karna Yudibrata Dkk, Bagbagan Makéna Basa Sunda (Bandung: Rahmat Cijulang, 1990), 46-47; Hidayat Suryalaga, "Ngungkulan Bangbaluh Ngagunakeun Undak Usuk Basa," in Kempelan Makalah Kongres Basa Sunda VIII, Subang 28-30 Juni, 2005, 149.
}

20. Anjeunna (Sulaéman) marios (pasukan) manuk, teras nyarios, "Naha kuring téh bet henteu ningal Hudhud?Boa manéhna kaasup nuteu hadir?21. Tangtu baris sdihukum ku kuring ku hukuman nu beurat atawarékdipeuncit, kajaba lamun manéhnadatang ka kuring bari mawa alesan anu jelas."22. Henteu lila (jolmanukHudhudtéhdatang),

tuluymanéhnanyarita,

"Abdiparantosterangkanaperkawisanu tacankauningakuanjeun.Abdi

téhnembédongkap

NagriSaba'baringabantunwartospenting tur yakin(leresna) kanggoanjeun ${ }^{20}$.

Dialog Nabi Sulaiman dengan burung Hudhud pada terjemahan di atas menggunakan ragam bahasa hormat dan kurang hormat. Ketika Nabi Sulaiman berbicara sebagai orang pertama (O1), maka penerjemah menggunakan diksi bahasa kurang hormat atau loma (kuring, manehna, kaasup),karena yang menjadi lawan bicaranya (O2) adalah burung Hudhud. Tetapi, ketika Hudhud menjadi orang pertama (O1), maka penerjemah menggunakan diksi bahasa hormat atau lemes(abdi, parantos, terang, kauninga, anjeun, dongkap, ngabantun), karena yang menjadi lawan bicaranya $(\mathrm{O} 2)$ adalah Nabi Sulaiman.Di sini menunjukkan bahwa latar penerjemah sebagai pengguna bahasa Sunda memainkan peran sangat penting dalam memilih ungkapan ragam tingkatan bahasa yang tepat dalam menerjemah teks ayat.

Selain itu, bila dibandingkan dengan terjemahan Alquran versi pemerintah edisi sebelumnya tahun 1974/1975, maka penggunaan tingkatan bahasa Sunda dalam $A l$ Qur'an Miwah Tarjamahna jauh lebih halus dalam pemilihan diksi kosakatanya. Ini misalnya, tampak ketika menerjemahkan Q.S. Al-fa>tih\}ah/1: $\quad$ 5-6. Edisi 1974/1975

${ }^{20}$ Pemda Provinsi dan Kanwil Depag Jawa Barat, Al-Qur'an Miwah Tarjamahna Dina Basa Sunda, Bandung: Kerjasama Pemda Provinsi Jawa Barat, MUI, LPTQ, Kanwil Depag Jawa Barat., 489. 
menggunakan diksi kurang hormat, "Mung $\mathrm{ka}$ Alloh urang sadaya ibadah, sareng mung ka Alloh urang sadaya neda pitulung." 21 Ini berbeda dengan al-Qur'an Miwah Tarjamahnayang menggunakan diksi sangat halus, Mung ka Gusti Allah abdi sadaya ibadah, sareng mung ka Gusti Allah abdi sadaya neda pitulung ${ }^{22}$.Perbedaan tingkatan bahasa ini tidak akan didapatkan dalam alQur'an dan Terjemahnya ${ }^{23}$. Bahasa Indonesia yang diterjemah menjadi: "Hanya kepada Engkaulah kami menyembah dan hanya kepada Engkaulah kami mohon pertolongan."

Kedua, ungkapan idiomatik(idiomatic expressions) berupa kecap panganteuratau anteuran, seperti pok nyarita, jol datang, trét nulis, am dahar, dug saré, kuniang hudang, gék diuk, dan lainnya.Umumnya ungkapan idiomatik ini berfungsi untuk menunjukkan keterikatan pembicara dengan awal situasi atau juga pada cara dan ragam tindakan tersebut. Djajasudarma menyebutnya sebagai kecap anteuran atau pemarkah keaspekan inkonatif yang mencapai 421 kata dengan verbalnya ${ }^{24}$.Penggunaan kecap panganteur "pok nyarita dan jol datang" misalnya, tampak dalam terjemahan berikut:

Pok caritakeun $k u \quad$ hidep (Muhammad)...(QS. Al-Baqarah[2]: 94) ${ }^{25}$. Jeung jol baédatang ti tungtung kota, hiji

${ }^{21}$ Pemda Provinsi dan Kanwil Depag Jawa Barat, Tarjamah Al-Quräan Basa Sunda, Dikaluarkeun Ku Proyek Penerbitan Al-Qur'än Bahasa Sunda Jawa Barat, 2.

${ }^{22}$ Pemda Provinsi dan Kanwil Depag Jawa Barat, Al-Qur'an Miwah Tarjamahna Dina Basa Sunda, Bandung: Kerjasama Pemda Provinsi Jawa Barat, MUI, LPTQ, Kanwil Depag Jawa Barat., 3.

${ }^{23}$ Pemda Provinsi dan Kanwil Depag Jawa Barat, 6.

${ }^{24}$ T. Fatimah Djajasudarma, "Panalungtikan Basa Sunda Di Lingkungan Kodya Bandung (Program Panalungtikan Basa Sunda Rumaja," in Kongres Basa Sunda VIII, Subang, 28-30 Juni., 2005, 277-98.

${ }^{25}$ Pemda Provinsi dan Kanwil Depag Jawa Barat, Al-Qur'an Miwah Tarjamahna Dina Basa Sunda, Bandung: Kerjasama Pemda Provinsi Jawa Barat, MUI, LPTQ, Kanwil Depag Jawa Barat., 25. lalaki kalawan rurusuhan... (QS. $Y a>s i>n[36]: 20)^{26}$.

Selain menunjukkan keunikan idiom bahasa Sunda, penggunaan idiom kata berpengaruh terhadap makna. Kata jol baé datang seperti pada terjemah di atas misalnya, menunjukkan durasi datang yang spontan hampir tanpa jeda dan terikat pada awal situasi. Berbeda dengan terjemah bahasa Indonesia yang menggunakan kalimat "dan telah datang" yang tidak menegaskan spontanitas ${ }^{27}$.

Ketiga, keragaman kosakata. Dibanding bahasa Indonesia, bahasa Sunda memiliki lebih banyak pilihan kosakata yang memiliki arti dekat atau sinonim dan boleh jadi jarang digunakan dalam bahasa Sunda sehari-hari. Pilihan kosakata sinonim yang kaya itu membuat antara satu kata dengan kata yang lain diterjemahkan secara berbeda-beda sesuai bahasa sumber. Misalnya, ra'ä (ningali /Q.6:76), nazar (marelong/Q.9:127) dan bașar (nénjo/Q.2:17) yang dalam bahasa Indonesia diterjemahkan dengan "melihat"; khawf (kasalempang/Q.2:38) dan khashyah (sieun/Q.36:11) berarti "takut," kämilah (sapuratina/Q.16:25) dan tamäm (nyampurnakeun/Q.6:154) berarti "sempurna."

Demikian beberapa karakteristik penting bahasa Sunda dalam Al-Qur'an Miwah Tarjamahna.Penerjemah menyadari bentuk kekhasan bahasa Sunda tersebut yang membedakan dengan bahasa lainnya.Tetapi, karakteristik bahasa Sunda tersebut belakangan semakin kurang disadari dan diketahui oleh generasi muda Sunda. Penjelasan berikutnya fokus pada tanggapan generasi milenial Sunda terhadap terjemahandalam Al-Qur'an Miwah Tarjamahna yang didasarkan pada penggunaan beberapa karakteristik bahasa Sundanya tersebut.

\section{Tanggapan Generasi Milenial Sunda}

\footnotetext{
${ }^{26}$ Pemda Provinsi dan Kanwil Depag Jawa Barat, 705.

27 Djajasudarma, "Kecap Anteuran Basa Sunda: Satu Kajian Semantik Dan Struktur,” 17.
} 
Pada bagian ini akan dijelaskan tentang pandangan generasi milenial Sundaterhadap terjemahan Sunda dalam Al-Qur'an Miwah Tarjamahna. Peneliti melakukan teknik penugasan kepada mahasiswa angkatan 2015 (semester VI) pada Prodi IAT Fakultas Ushuluddin UIN Bandung untuk mengisi kolom tanggapan berupa kata atau kalimat yang kurang dipahami. Terdapat lima kelas mahasiswa IAT.Setiap kelas mendapatkan tugas enam juz'yang didistribusikan pada setiap mahasiswa.Tidak semua mahasiswa dilibatkan untuk tugas tersebut mengingat tidak semuanya orang Sunda. Sebagian kecil mahasiswa berasal dari etnis Jawa, Aceh, Padang, Betawi, dan lainnya. Dari total 203 mahasiswa, terdapat sekitar 177 mahasiswa Sunda.Berikut tabel penugasan sesuai dengan jumlah kelas dan mahasiswa:

\begin{tabular}{|c|c|c|}
\hline $\begin{array}{c}\text { Kela } \\
\text { s }\end{array}$ & $\begin{array}{c}\text { Jumlah } \\
\text { Mahasiswa }\end{array}$ & Penugasan \\
\hline A & 44 & Juz' $1-5$ \\
\hline B & 43 & Juz' 6-10 \\
\hline C & 45 & Juz' $11-20$ \\
\hline D & 34 & Juz' $21-25$ \\
\hline E & 37 & Juz' 26-30 \\
\hline
\end{tabular}

Tabel 1: Penugasan Mahasiswa IAT Angkatan 2015

Penugasan yang diberikan berupa kolom terjemahan dari Al-Qur'an Miwah Tarjamahna, kolom isian "kata yang kurang dipahami" dan kolom "usulan."Kolom isian "kata yang kurang dipahami"dibuat untuk mengetahui struktur kata yang asing dan sulit dimengerti. Kata tersebut boleh jadi tidak lagi mereka temukan dalam percakapan seharihari. Setelah dikumpulkan, hasil penugasan tersebut kemudian diidentifikasi dan dikelompokkan. Tidak semua data hasil penugasan mahasiswa IAT berupa tanggapan atas terjemahan Al-Qur'an Miwah Tarjamahna (30 Juz atau 114 surah)tersebut ditampilkan di sini, karena terlampau banyak. Penulis hanya akan menampilkan data hasil penugasan mahasiswa IAT tersebut dari Surah Al-fa>tih\}ah dan Al-Baqarah (Juz 1-3).
Berikut daftar beberapa kata dari dua surah tersebut yang kurang bisa dipahami oleh mereka. Beberapa kata yang disebut berulangulang hanya akan dicantumkan satu kali.

\begin{tabular}{|l|l|l|}
\hline No & $\begin{array}{l}\text { Nama } \\
\text { Surah }\end{array}$ & $\begin{array}{l}\text { Kata yang } \\
\text { dipahami }\end{array}$ \\
\hline 1. & $\begin{array}{l}\text { Al- } \\
\text { fa>tih\}a } \\
\text { h }\end{array}$ & $\begin{array}{l}\text { murbéng, } \text { ngagem, } \\
\text { wawales, neda }\end{array}$ \\
\hline 2. & $\begin{array}{l}\text { Al- } \\
\text { Baqarah }\end{array}$ & $\begin{array}{l}\text { satemenna, wawadian, } \\
\text { poma, satemen-temen, } \\
\text { beber, hamo, } \\
\text { ngalimpudan, méh, } \\
\text { ngaharintul, } \\
\text { patinggulidag, lingsem, } \\
\text { nyasabkeun, pati-pati, } \\
\text { pasék, ngaludar, } \\
\text { dipaheutkeun, sapuratina, } \\
\text { neja, hidep, unjukan, } \\
\text { kendat, } \text { ngawuruk, } \\
\text { rumaos, kajabi, } \\
\text { ngadawuh, } \\
\text { nalika,mungpung, } \\
\text { dikusrukkeun, satruna, } \\
\text { padumukan, saéstuna, } \\
\text { pituduh, tanwandé, } \\
\text { pinanggih, } \\
\text { kasalempangan, nohonan, } \\
\text { nyamunikeun, adegkeun, } \\
\text { baris jonghok, sagara, } \\
\text { pasini, meredih, } \\
\text { rumbahna, kungsi, } \\
\text { wangkelang jeung } \\
\text { ngarempak wates, } \\
\text { milampah, da cacak, } \\
\text { cegahan, pieunteungeun, } \\
\text { nimbalan, ngawuluku, } \\
\text { sidem-sidem, mintonkeun, } \\
\text { ajrih, sangkaku, akon, } \\
\text { maléngos, diténgténgkeun, } \\
\text { sapagodos, bebendon, } \\
\text { pohara, maténi, } \\
\text { mungguhing, diajangkeun, } \\
\text { saniskara, sawatara, } \\
\text { culangung, cawiskeun, } \\
\text { dinasakh, medal, écés, }\end{array}$ \\
\hline
\end{tabular}




\begin{tabular}{|l|}
\hline hojah, anu ngagem, \\
angen-angen, pinanggih, \\
ageman, dipacogrégkeun, \\
réka perdaya, sugri nu \\
kumelip, sumujud, \\
ngayuga, nétélakeun, \\
pangaweruh, biluk, \\
panangtayungan, tinangtu, \\
nedunan, tansah, \\
pamungkas, ceuceub, \\
tinangtos, katut, \\
pacéngkadan, sibgah, \\
celupan, maduan, \\
panyaksén, lalieun, \\
kumambang, angar, \\
mintonkeun, satru \\
kabuyutan, tumiba, \\
jembar, katarajang, sakur, \\
sangkan, sapatemon, atra, \\
pacuan, wanci, pinanggih, \\
prung, mangkadé, prung \\
baé ayonan, wawales, \\
eureun, ka taya, \\
panarajangna, lubar, \\
nyarengan, waka, \\
nyampak, manggih, \\
peunciteun, nyuprih, \\
kurnia, bral, micangcam, \\
sinareng, balitunganana, \\
mantenna, mincut, lumaku, \\
tutuwuhan, sasatoan, \\
adigungna, padumukan, \\
welas asih, tapaklacak, \\
tétélan, tibatan, kalawan \\
widi, sawarga, \\
digénjlongkeun, kauninga, \\
dipikaceuceub, \\
sabudereunna, kumbuh, \\
ngécéskeun, kareseban, \\
ngadeuheusan, aris, \\
lamun, séjén, \\
kamudharatan, béak, \\
weruh, numpurkeun, \\
kamampuhan, \\
ditangtukeun, upama, \\
nerangkeun, poék- \\
mongkléng, niténan, \\
\end{tabular}

\begin{tabular}{|l|l|}
\hline bireungeuh, baris, dibulen, \\
petana, hateup-hateupna, \\
kantenan pisan, calukan, \\
ngadongdolékeun, \\
pinanggih, pengkuh, \\
patinggolontor, mangsa \\
kolot, ledis, ngébréhkeun, \\
rerencepan, nyuprih, \\
karisi, karémpan, \\
karanjingan, karerepet, \\
pangwales, mumpang, \\
saluyuan, diangkir, \\
panyaksén, crung-créng, \\
satengahing, sawadina, \\
tendon, kumelip, \\
satungkebing, ngabénten, \\
tuhu, pangwangsulan, \\
anging, kenging, \\
kahadéan, dipilampah, \\
midamel, nibankeun, \\
momot, abot, saméméh, \\
beungbeurat, kalayan, \\
pananggeuhan, margi, \\
pitulung, sétan-sétanna, \\
jeung nu moal téa \\
maranéh teu pibisaeun \\
nyieun, maranéhna \\
meredih deui," pamugi \\
anjeun naroskeun deui ka \\
pangéran anjeun, supaya \\
mantenna nerangkeun ka \\
kuring saréréa, nu kumaha \\
sabenerna éta sapi téh, \\
lantaran saéstuna masih \\
samar keur kuring saréréa \\
mah, ngiderkeun, \\
lulubaran, jonghok, nénjo, \\
neumbleuhkeun, \\
pamohalan, bodo balilu, \\
dicalukan, ngadéngé, \\
gero, diancokeun, yén, tur, \\
prak, bral geura mariang, \\
karuhun, kasaéan, kinten \\
énggal balitunganana, \\
pohara banget, pok, kieu, \\
tah, téh, pék, upami, \\
diumpamakeun,
\end{tabular}




\begin{tabular}{|l|l|}
\hline & $\begin{array}{l}\text { picilakaeun, séép, uninga, } \\
\text { ngadagoan, ngantosan, } \\
\text { pangabisa, ditangtoskeun, } \\
\text { dupi, pananggeuhan. }\end{array}$ \\
\hline
\end{tabular}

Tabel 2: Kosakata yang kurang dipahami oleh mahasiswa

Dari sejumlah daftar kata yang kurang dipahami olehpara mahasiswa IAT tersebut, penulis kemudian mengidentifikasi dan mengelompokkannya ke dalam tigajenis, yakni kata yang termasuk tatakrama bahasa, ungkapan idiomatik dan ragamkosakata lama. Berikut beberapa contoh kata yang ditandai oleh merekaketika membacaAl-Qur'an Miwah TarjamahnaSurah Al-fa>tih\}ah dan AlBaqarah (Juz 1-3):

\section{a. Tingkatan bahasa}

\begin{tabular}{|c|c|c|}
\hline Q.S. & $\begin{array}{l}\text { Terjemahan dalam } \\
\text { Al-Qur'an Miwah } \\
\text { Tarjamahna }\end{array}$ & $\begin{array}{l}\text { Kata yang } \\
\text { kurangdipaha } \\
\text { mi }\end{array}$ \\
\hline $1: 2$ & $\begin{array}{lr}\text { Sadaya } & \text { puji } \\
\text { kagungan } & \text { Allah. } \\
\text { Pangéran } & n u \\
\text { murbéng } & \text { sakumna } \\
\text { alam. } & \end{array}$ & $\begin{array}{l}\text { murbéng } \\
\text { (menguasai) }\end{array}$ \\
\hline $1: 4$ & $\begin{array}{lr}\text { Nu } & \text { ngagem } \\
\text { kakawasaan dina } \\
\text { dinten wawales } \\
\text { (kiamat). }\end{array}$ & $\begin{array}{l}\text { ngagem(meme } \\
\text { gang), } \\
\text { wawales(pemb } \\
\text { alasan) }\end{array}$ \\
\hline $1: 5$ & $\begin{array}{l}\text { Mung ka gusti abdi } \\
\text { sadaya ibadah, } \\
\text { sareng mung ka } \\
\text { gusti sadaya neda } \\
\text { pitulung }{ }^{28} \text {. }\end{array}$ & $\begin{array}{l}\text { neda } \\
\text { (memohon) }\end{array}$ \\
\hline
\end{tabular}

Tabel 3: Tatakrama bahasa yang kurang dipahami oleh mahasiswa

Ketika membaca terjemahan QS. Alfa>tih\}ah dalam Al-Qur'an Miwah Tarjamahnatersebut, para mahasiswa IAT menandai beberapa kata yang menurut

${ }^{28}$ Pemda Provinsi dan Kanwil Depag Jawa Barat, Al-Qur'an Miwah Tarjamahna Dina Basa Sunda, Bandung: Kerjasama Pemda Provinsi Jawa Barat, MUI, LPTQ, Kanwil Depag Jawa Barat., 3-4. pandangannya kurang dipahami, yakni kata murbéng(menguasai), ngagem(memegang), wawales(pembalasan) dan neda(memohon). Keempat kata tersebut termasuk ke dalam jenis ragam bahasa hormat dan sangat halus (lemes), karena digunakan untuk objek atau lawan bicara yang kedudukannya lebih tinggi, yaitu Allah. ${ }^{29}$ Ragam bahasa hormat tersebut, selain untuk Allah, digunakan juga untuk manusia (misalnya raja) dengan melihat dalam hal usia, kedudukan, pangkat, tingkat keakraban serta situasi di antara yang disapa dan yang menyapa, atau antara pembicara, lawan bicara, dan yang dibicarakan ${ }^{30}$.Para mahasiswa IAT tampak kurang begitu akrab dengan tata krama bahasa hormat dan sangat halus tersebut. Hal ini disebabkan karena keempat kata tersebut jarang mereka temui dalam percakapan sehari-hari.

Kata murbéng misalnya, termasuk kata yang arkhais dan lama, berasal dari kata murba, akar katanya purba. Kata purba berarti kawasa (kuasa).Misalnya, ungkapan $\mathrm{Nu}$ Murba Wisésa (Gusti Allah yang Maha Kuasa). Kata ini sangat halus dan tidak digunakan kecuali untuk Tuhan atau raja. Sedangkan kata kasar atau loma, biasanya digunakan kata kawasa. Begitu pun dengan kata ngagemyangberasal dari kata agem,berarti nyekel (memegang), seperti ungkapan ngagem agama Islam (memegang atau menganut agama Islam); ageman (pegangan atau anutan). Kata ngagem dalam arti memegang kekuasaan sangat jarang digunakan dibanding dalam makna anutan agama. Sedangkan kata wawales berasal dari kata bales (membalas), sehingga bermakna balasan Gusti Allah. Terakhir, kata neda mengandung dua makna, yakni makan dan

${ }^{29}$ Hasil Penugasan Terjemahan Al-Qur'an Basa Sunda, Mahasiswa IAT Angkatan 2015 Semester VI Kelas A, B, C, D, E periode Februari-Mei 2019, Prodi Ilmu Al-Qur'an dan Tafsir, Fakultas Ushuluddin, UIN Sunan Gunung Djati Bandung.

30 Anderson, "Speech Levels: The Case of Sundanese," 107. 
meminta. Keduanya merupakan kata yang sangat halus bagi diri sendiri. Kata neda kemudian berkembang menjadi neda-neda, neneda (memohon moga-moga); peneneda (permohonan); mangnedakeun (mendoakan); kateda(diterima dengan senang hati) ${ }^{31}$.

\section{b. Ungkapan Idiomatik}

Para mahasiswa IAT yang lahir di era milenial sekarang umumnya kesulitan untuk mengenali ungkapan idiomatik Sunda yang menunjukkan keterikatan pembicara dengan awal situasi dalam suatu tindakan. Salah seorang mahasiswa, NF misalnya, menyatakan bahwa sebabnya adalah karena ungkapan idiomatik itu jarang ditemukan dalam bahasa lisan yang mereka pakai sehari-hari ${ }^{32}$.Berikut beberapa contoh ungkapan idiomatik atau kecap anteuran yang kurang dipahami oleh mahasiswa IAT berdasarkan hasil penugasan terjemahan atas surah Al-Baqarah[2]: ${ }^{33}$

\begin{tabular}{|l|l|l|}
\hline Q.S. & $\begin{array}{l}\text { Terjemahan } \\
\text { dalam Al- } \\
\text { Qur'an Miwah } \\
\text { Tarjamahna }\end{array}$ & $\begin{array}{l}\text { Kata yang } \\
\text { kurangdipahami }\end{array}$ \\
\hline 2: 190 & $\begin{array}{l}\text { Prung geura } \\
\text { perangan ku } \\
\text { aranjeun dina } \\
\text { jalan Allah } \\
\text { jalma-jalma } \\
\text { anu merangan } \\
\text { ka } \\
\text { aranjeun...34 }\end{array}$ & \\
perangan(perangi \\
2: 196 & Prak geura & \\
\hline
\end{tabular}

31 R. Satjadibrata, Kamus Basa Sunda (Bandung: Kiblat, 2005), 310,37,56,389.

32 Jajang A.Rohmana, Wawancara dengan NF, mahasiswa IAT Semester VI D (2019).

${ }^{33}$ Jajang A Rohmana, "Hasil Penugasan Terjemahan Alquran Basa Sunda, Mahasiswa IAT Angkatan 2015 Semester VI Kelas A, B, C, D, E (Periode Februari-Mei 2019), Prodi Ilmu Alquran Dan Tafsir, Fakultas Ushuluddin, UIN Sunan Gunung Djati Bandung." (Bandung, 2019).

${ }^{34}$ Pemda Provinsi dan Kanwil Depag Jawa Barat, Al-Qur'an Miwah Tarjamahna Dina Basa Sunda, Bandung: Kerjasama Pemda Provinsi Jawa Barat, MUI, LPTQ, Kanwil Depag Jawa Barat., 45.

\begin{tabular}{|c|c|c|}
\hline & $\begin{array}{l}\text { sampurnakeun } \\
\text { ku aranjeun } \\
\text { ibadah haji } \\
\text { jeung umrah } \\
\text { karana } \\
\text { Allah... }\end{array}$ & $\begin{array}{l}\text { sampurnakeun(se } \\
\text { mpurnakanlah) }\end{array}$ \\
\hline 2: 199 & 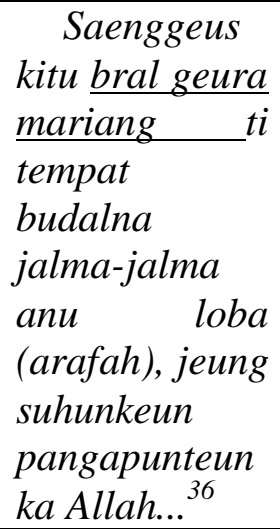 & $\begin{array}{c}\text { bral geura } \\
\text { mariang }\end{array}$ \\
\hline $2: 223$ & $\begin{array}{l}\text { Ari bojo-bojo } \\
\text { aranjeun téh } \\
\text { ibarat kebon } \\
\text { aranjeun ku } \\
\text { sabab kitu, pék } \\
\text { datangan éta } \\
\text { kebon-kebon } \\
\text { aranjeun } \\
\text { téhkumaha } \\
\text { waé sakarep } \\
\text { aranjeun. }{ }^{37} .\end{array}$ & pék datangan \\
\hline
\end{tabular}

Tabel 4: Ungkapan idiomatik yang kurang dipahami oleh mahasiswa

Tabel di atas menunjukkan bahwa para mahasiswa kurang memahami ungkapan idiomatik dalam bahasa Sunda, seperti prung geura perangan(segeralah berperang), prak geura sampurnakeun(segeralah sempurnakan), bral geura mariang(segeralah berangkat), dan pék datangan(datangilah). Padahal ia merupakan ciri yang memperkuat rasa bahasa Sunda dalam Al-Qur'an Miwah Tarjamahna. Ungkapan idiomatik prung misalnya,

\footnotetext{
${ }^{35}$ Pemda Provinsi dan Kanwil Depag Jawa Barat, 46.

${ }^{36}$ Pemda Provinsi dan Kanwil Depag Jawa Barat, 47.

37 Pemda Provinsi dan Kanwil Depag Jawa Barat, 53.
} 
mengandung makna perintah yang pasti dan spontan untuk segera dan tidak menunggu waktu lama untuk memulai. Kata ini bukan hanya digunakan untuk peperangan, tetapi juga permainan atau tontonan, seperti prung maén (mulailah bermain). ${ }^{38}$ Karenanya, kata prung geura perang menunjukkan ungkapan spontan untuk segera memulai berperang tanpa menunggu lama. Ini berbeda dengan ungkapan geura perangan yang tidak menunjukkan makna pasti kapan penyegeraan itu dimulai.

Hal yang sama juga tampak pada kata prak geura sampurnakeun danbral geura mariang. Kata prak sebetulnya merupakan ungkapan idiomatik untuk berbagai perbuatan, seperti prak geura pigawéatau prak geura lakukeun(segeralah kerjakan). ${ }^{39}$ Kata prak geura sampurnakeunpada terjemahan di atas menunjukkan ucapan spontan dan pasti agar segera menyempurnakan ibadah haji itu tanpa menunggu waktu lama. Begitu juga kata bral geura mariang berarti segeralah berangkat (ke Arafah). Awalnya kata bral khusus untuk berangkat dengan berjalan kaki, tetapi sekarang digunakan untuk keberangkatan apapun, baik berjalan atau berkendaraan. ${ }^{40}$ Sedang kata pék datangan menunjukkan ungkapan pasti dan spontan untuk"mendatangi"'istri sekehendakmu. ${ }^{41}$

Semua terjemahan dengan ungkapan idiomatik tersebut menunjukkan bahwa $\mathrm{Al}$ Qur'an Miwah Tarjamahna sudah dengan cukup baik menggunakan struktur bahasa Sunda, sehingga terasa sangat nyunda. Tetapi,hal ini ternyata berbeda dengan tanggapan mahasiswa IAT yang kurang paham dengan kosakata tersebut, karena boleh jadi jarang mereka temui dalam percakapan seharihari.

\section{c. Ragam Kosakata Lama}

\footnotetext{
${ }^{38}$ Satjadibrata, Kamus Basa Sunda, 307.

${ }^{39}$ Satjadibrata, 306.

${ }^{40}$ Satjadibrata, 79.

${ }^{41}$ Satjadibrata, 289.
}

Selain tingkatan bahasa dan ungkapan idiomatik, mahasiswa IAT juga kurang bisa memahami sejumlahkosakata lama yang sudah sangat jarang digunakan dalam percakapan sehari-hari. Tidak mudah menentukan batasan kosakatalama atau tidak dalam bahasa Sunda, karena sangat tergantung pengetahuan setiap mahasiswa. Tetapi, penulis mengukurnya dengan mengkonfirmasi pada beberapa penulis Sunda dan karangan berbahasa Sunda, seperti kamus, buku, kumpulan carpon(cerpen) dan majalah.Beberapa kosakata yang tidak lagi digunakan dalam karangan tersebut dikategorikan sebagai bahasa Sunda lama. Sebaliknya, kosakata yang masih digunakan berarti tidak termasuk lama. Berikut beberapa contoh ragam kosakata lama dalam Al-Qur'an Miwah Tarjamahna yang kurang dipahami oleh mahasiswa IAT:

\begin{tabular}{|c|c|c|}
\hline Q.S. & $\begin{array}{l}\text { Terjemahan dalam } \\
\text { Al-Qur'an Miwah } \\
\text { Tarjamahna }\end{array}$ & $\begin{array}{l}\text { Kata yang } \\
\text { kurangdipaha } \\
\text { mi }\end{array}$ \\
\hline $2: 26$ & $\begin{array}{l}\text { Saenyana Allah } \\
\text { henteu lingsem teu } \\
\text { sing ngadamel } \\
\text { misil } \\
\text { (babandingan) } \\
\text { kunaon baé oge. }{ }^{42}\end{array}$ & lingsem (malu) \\
\hline $2: 36$ & $\begin{array}{lr}\text {.. jeung } & \text { Kami } \\
\text { ngadawuh kieu, } & \text { "Jung geura indit } \\
\text { "Jurun aranjeun, } \\
\text { luruni sawaréh ti } \\
\text { bari } \\
\text { aranjeun jadi } \\
\text { satruna } \\
\text { sawaréhna deui, } \\
\text { jeung nu } \\
\text { aranjeun di éta } \\
\text { bumi disadiakeun } \\
\text { tempat padumukan }\end{array}$ & $\begin{array}{l}\text { satruna(musuh } \\
\text { nya),padumuk } \\
\text { an(tempat } \\
\text { tinggal) }\end{array}$ \\
\hline
\end{tabular}

${ }^{42}$ Pemda Provinsi dan Kanwil Depag Jawa Barat, Al-Qur'an Miwah Tarjamahna Dina Basa Sunda, Bandung: Kerjasama Pemda Provinsi Jawa Barat, MUI, LPTQ, Kanwil Depag Jawa Barat., 11. 


\begin{tabular}{|c|c|c|}
\hline & $\begin{array}{lr}\text { jeung } & \text { kasenangan } \\
\text { nepi } & \text { ka } \\
\text { mangsa } & \text { hiji } \\
\text { ditangtukeun)!, } 44\end{array}$ & \\
\hline $2: 38$ & 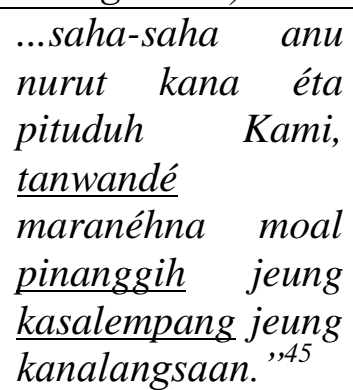 & $\begin{array}{l}\text { tanwande(pasti } \\
\text { ), } \\
\text { pinanggih(men } \\
\text { dapatkan), } \\
\text { kasalempang(k } \\
\text { ekhawatiran) }\end{array}$ \\
\hline 2: 104 & 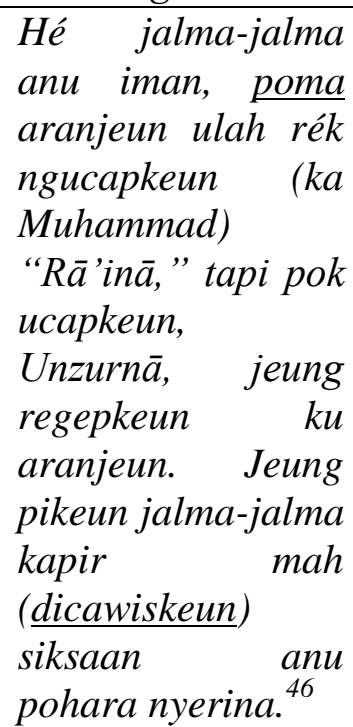 & $\begin{array}{l}\text { poma } \\
\text { (hendaknya), } \\
\text { dicawiskeun } \\
\text { (disediakan) }\end{array}$ \\
\hline 2: 108 & 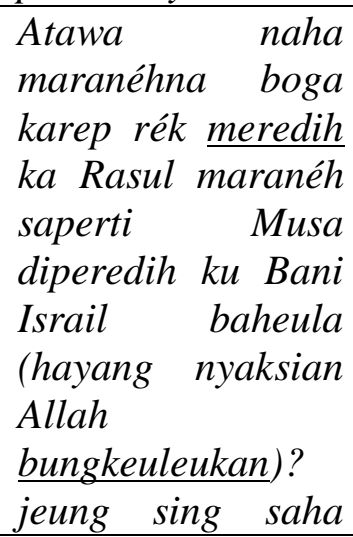 & $\begin{array}{l}\text { meredih } \\
\text { (memohon), } \\
\text { bungkeuleukan } \\
\text { (kelihatan } \\
\text { nyata), } \\
\text { katalimbeng } \\
\text { (bingung), }\end{array}$ \\
\hline
\end{tabular}

${ }^{43}$ Satjadibrata, Kamus Basa Sunda, 307.

44 Pemda Provinsi dan Kanwil Depag Jawa Barat, Al-Qur'an Miwah Tarjamahna Dina Basa Sunda, Bandung: Kerjasama Pemda Provinsi Jawa Barat, MUI, LPTQ, Kanwil Depag Jawa Barat., 13.

${ }^{45}$ Pemda Provinsi dan Kanwil Depag Jawa Barat, 13. 27.

$\mid$\begin{tabular}{lr} 
anu nukeurkeun \\
iman ru & ku \\
kakupuran, & \\
satemenna & \\
manéhna reus & tina \\
katalimbeng ran & anu \\
jalan & \\
lempeng. & \\
\hline
\end{tabular}

Tabel 5: Ragam kosakata lama yang kurang dipahami oleh mahasiswa

Tabel di atas menunjukkan bahwa mahasiswa IAT tersebut kurang memahami ragam kosakata Sunda, sepertilingsem (malu), satruna (musuhnya), padumukan (tempat tinggal), tanwandé(pasti), pinanggih (mendapatkan), kasalempang (kekhawatiran), poma (hendaknya), dicawiskeun (disediakan), meredih (memohon), bungkeuleukan (kelihatan nyata) dan katalimbeng (bingung). ${ }^{48}$ Salah satu sebabnya adalah karena kosakata tersebut sudah jarang digunakan dalam percakapan mereka sehari-hari.

Bagi mereka, beberapa kosakata tersebut boleh jadi dianggap sebagai kosakataSunda lama yang digunakan oleh orang Sunda dulu. Beberapa penulisdan karangan Sunda didapati masih menggunakan kata-kata tersebut. Misalnya, kamus, ${ }^{49}$ buku, kumpulan carpon dan majalah Sunda. Sehingga anggapan mahasiswa tersebut terhadap kosakata Sunda belum tentu sama dengan orang Sunda lainnya terutama generasi lama.Ini menunjukkan bahwa terdapat kesenjangan antara mahasiswa generasi milenial dengan orang Sunda lainnya dalam berbahasa.Mahasiswa sekarang umumnya lebih sering berkomunikasi dengan

${ }^{47}$ Pemda Provinsi dan Kanwil Depag Jawa Barat, Tarjamah Al-Quräan Basa Sunda, Dikaluarkeun Ku Proyek Penerbitan Al-Qur'än Bahasa Sunda Jawa Barat, 28.

${ }^{48}$ Rohmana, "Hasil Penugasan Terjemahan Alquran Basa Sunda, Mahasiswa IAT Angkatan 2015 Semester VI Kelas A, B, C, D, E (Periode Februari-Mei 2019), Prodi Ilmu Alquran Dan Tafsir, Fakultas Ushuluddin, UIN Sunan Gunung Djati Bandung.”

49 Satjadibrata, Kamus Basa Sunda, 231,348,117,382,280,339,304,94,294,83,377. 
menggunakan bahasa Sunda populer yang terpengaruh oleh bahasa lainnya ${ }^{50}$ dan semakin jarang mengakses literatur Sunda. Sehingga bisa dipahami bila mereka kurang bisa memahami terjemahan bahasa Sunda dalam Al-Qur'an Miwah Tarjamahna.

\section{Usulan Kata dalam Terjemahan Alquran Bahasa Sunda}

Setelah para mahasiswa IAT memberikan tanggapan atas terjemahan yang kurang bisa dipahami dalam Al-Qur'an Miwah Tarjamahna, kemudian mereka memberikan usulan kosakata Sunda sebagai alternatif terjemahan. Usulan ini penting untuk memberikan ruang bagi mereka, sehingga bisa diketahuikosakataapa saja yang menurut mereka lebih populer dan mudah dipahami. Tidak semua usulan kata yang diberikan mahasiswa akan ditampilkan di sini. Berikut beberapa contoh usulan kosakatatersebut:

\begin{tabular}{|c|c|c|c|}
\hline Q.S. & $\begin{array}{l}\text { Terjema } \\
\text { han } \\
\text { dalam } \\
\text { Al- } \\
\text { Qur'an } \\
\text { Miwah } \\
\text { Tarjama } \\
\text { hna }\end{array}$ & $\begin{array}{l}\text { Kata } \\
\text { yang } \\
\text { kurang } \\
\text { dipaha } \\
\text { mi }\end{array}$ & $\begin{array}{l}\text { Usulan kata } \\
\text { populer }\end{array}$ \\
\hline $1: 2$ & $\begin{array}{l}\text { Sadaya } \\
\text { puji } \\
\text { kagunga } \\
n \text { Allah. } \\
\text { Pangéra } \\
n \quad \text { nu } \\
\text { murbéng } \\
\text { sakumna } \\
\text { alam. }\end{array}$ & $\begin{array}{l}\quad \text { mur } \\
\text { béng } \\
\text { (mengu } \\
\text { asai) }\end{array}$ & ngawasa \\
\hline $1: 4$ & $\begin{array}{l}\mathrm{Nu} \\
\text { ngagem } \\
\text { kakawas }\end{array}$ & $\begin{array}{l}\quad n g a g \\
\text { em(me } \\
\text { megang }\end{array}$ & $\begin{array}{c}\text { nyepeng, } \\
\text { pangbalesan }\end{array}$ \\
\hline
\end{tabular}

${ }^{50}$ Oyon Sofyan Sobarna, Cece., Djajasudarma, T. Fatimah.,Umsari, Kehidupan Bahasa Sunda Di Lingkungan Remaja Kodya Bandung (Jakarta: Pusat Pembinaan dan Pengembangan Bahasa, Departemen Pendidikan dan Kebudayaan, 1997), 76-79.

\begin{tabular}{|c|c|c|c|}
\hline & $\begin{array}{l}\text { aan dina } \\
\text { dinten } \\
\underline{\text { wawales }} \\
\text { (kiamat). }\end{array}$ & $\begin{array}{l}\text { ), } \\
\text { wawale } \\
\text { s(pemb } \\
\text { alasan) }\end{array}$ & \\
\hline $1: 5$ & $\begin{array}{l}\text { Mung ka } \\
\text { Gusti } \\
\text { abdi } \\
\text { sadaya } \\
\text { ibadah, } \\
\text { sareng } \\
\text { mung ka } \\
\text { Gusti } \\
\text { sadaya } \\
\text { neda } \\
\text { pitulung. }\end{array}$ & $\begin{array}{l}\text { neda } \\
\text { (memo } \\
\text { hon) }\end{array}$ & $\begin{array}{l}\text { Nyuhunke } \\
\text { un }\end{array}$ \\
\hline $2: 26$ & $\begin{array}{l}\text { Saenyan } \\
\text { a Allah } \\
\text { henteu } \\
\text { lingsem } \\
\text { teu sing } \\
\text { ngadame } \\
\text { l misil } \\
\text { (babandi } \\
\text { ngan) } \\
\text { kunaon } \\
\text { baé } \\
\text { ogé... } 52\end{array}$ & $\begin{array}{l}\text { lings } \\
\text { em } \\
\text { (malu) }\end{array}$ & Isin \\
\hline $2: 36$ & $\begin{array}{l}\text {...jeung } \\
\text { Kami } \\
\text { ngadawu } \\
h \quad \text { kieu, } \\
\text { “Jung } \\
\text { geura } \\
\text { indit } \\
\text { turun } \\
\text { aranjeun } \\
, \quad \text { bari } \\
\text { sawaréh } \\
\text { ti }\end{array}$ & $\begin{array}{l}\quad \text { satru } \\
\text { na(mus } \\
\text { uhnya), } \\
\text { padumu } \\
\text { kan(te } \\
\text { mpat } \\
\text { tinggal) }\end{array}$ & $\begin{array}{c}\text { musuhna, } \\
\text { tempat cicing }\end{array}$ \\
\hline
\end{tabular}

${ }^{51}$ Pemda Provinsi dan Kanwil Depag Jawa Barat, Al-Qur'an Miwah Tarjamahna Dina Basa Sunda, Bandung: Kerjasama Pemda Provinsi Jawa Barat, MUI, LPTQ, Kanwil Depag Jawa Barat., 3-4.

${ }_{52}$ Pemda Provinsi dan Kanwil Depag Jawa Barat, 11. 
Alquran dan Bahasa Sunda Populer:

Respons Generasi Milenial terhadap Terjemahan Alquran Bahasa Sunda

\begin{tabular}{|c|c|c|c|}
\hline & $\begin{array}{l}\text { aranjeun } \\
\text { jadi } \\
\text { satruna } \\
\text { nu } \\
\text { sawaréh } \\
\text { na deui, } \\
\text { jeung } \\
\text { keur } \\
\text { aranjeun } \\
\text { di éta } \\
\text { bumi } \\
\text { disadiak } \\
\text { eun } \\
\text { tempat } \\
\text { padumuk } \\
\text { an jeung } \\
\text { kasenan } \\
\text { gan nepi } \\
\text { ka hiji } \\
\text { mangsa } \\
\text { (nu } \\
\text { ditangtu } \\
\text { keun)!'” } \\
\text { 53 }\end{array}$ & & \\
\hline $2: 38$ & $\begin{array}{l}\text {... saha- } \\
\text { saha anu } \\
\text { nurut } \\
\text { kana éta } \\
\text { pituduh } \\
\text { Kami, } \\
\text { tanwand } \\
\underline{e} \\
\text { maranéh } \\
\text { na moal } \\
\text { pinanggi } \\
\underline{h} \text { jeung } \\
\underline{\text { kasalem }} \\
\text { pang } \\
\text { jeung } \\
\text { kanalan } \\
\text { gsaan." } \\
\text { 54 }\end{array}$ & $\begin{array}{l}\quad \text { tanw } \\
\text { ande(pa } \\
\text { sti), } \\
\text { pinang } \\
\text { gih(me } \\
\text { ndapatk } \\
\text { an), } \\
\text { kasale } \\
\text { mpang( } \\
\text { kekhaw } \\
\text { atiran) }\end{array}$ & $\begin{array}{r}\text { pasti, } \\
\text { panggih, } \\
\text { kasieun. }\end{array}$ \\
\hline
\end{tabular}

53 Pemda Provinsi dan Kanwil Depag Jawa Barat, 13. 13.

\begin{tabular}{|c|c|c|c|}
\hline 2: 104 & 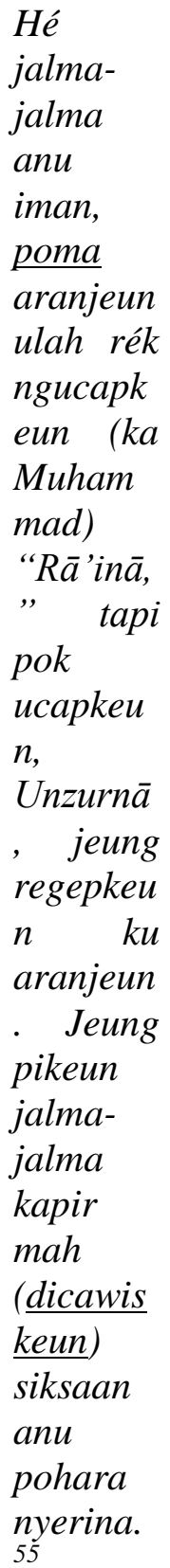 & $\begin{array}{l}\quad \text { pom } \\
\text { a } \\
\text { (hendak } \\
\text { nya), } \\
\text { dicawis } \\
\text { keun } \\
\text { (disedia } \\
\text { kan) }\end{array}$ & $\begin{array}{c}\text { ulah, } \\
\text { disadiakeun. }\end{array}$ \\
\hline $2: 108$ & $\begin{array}{l}\text { Atawa } \\
\text { naha } \\
\text { maranéh } \\
\text { na boga } \\
\text { karep } \\
\text { rék } \\
\text { meredih } \\
\text { ka Rasul } \\
\text { maranéh }\end{array}$ & $\begin{array}{l}\text { meredi } \\
h \\
\text { (memo } \\
\text { hon), } \\
\text { bungke } \\
\text { uleukan } \\
\text { (kelihat } \\
\text { an } \\
\text { nyata), }\end{array}$ & $\begin{array}{l}\text { nyuhunkeu } \\
n, \quad \text { kalawan } \\
\text { jelas, } \\
\text { nyalahan. }\end{array}$ \\
\hline
\end{tabular}

${ }^{55}$ Pemda Provinsi dan Kanwil Depag Jawa Barat, 27. 


\begin{tabular}{|c|c|c|c|}
\hline & $\begin{array}{l}\text { saperti } \\
\text { Musa } \\
\text { diperedi } \\
h \quad \text { ku } \\
\text { Bani } \\
\text { Israil } \\
\text { baheula } \\
\text { (hayang } \\
\text { nyaksian } \\
\text { Allah } \\
\text { bungkeul } \\
\text { eukan)? } \\
\text { Jeung } \\
\text { sing } \\
\text { saha anu } \\
\text { nukeurke } \\
\text { un iman } \\
\text { ku } \\
\text { kakupur } \\
\text { an, } \\
\text { satemen } \\
\text { na } \\
\text { manéhna } \\
\text { geus } \\
\text { katalimb } \\
\text { eng tina } \\
\text { jalan } \\
\text { anu } \\
\text { lempeng. } \\
56\end{array}$ & $\begin{array}{l}\text { katalim } \\
\text { beng } \\
\text { (bingun } \\
\text { g), }\end{array}$ & \\
\hline 2: 190 & $\begin{array}{l}\frac{\text { Prung }}{\text { geura }} \\
\text { peranga } \\
\underline{n} \quad k u \\
\text { aranjeun } \\
\text { dina } \\
\text { jalan } \\
\text { Allah } \\
\text { jalma- } \\
\text { jalma } \\
\text { anu } \\
\text { meranga } \\
n \quad k a\end{array}$ & $\begin{array}{l}\text { Prung } \\
\text { geura } \\
\text { perang } \\
\text { an } \\
\text { (perang } \\
\text { ilah) }\end{array}$ & $\begin{array}{l}\text { Geura } \\
\text { perangan }\end{array}$ \\
\hline
\end{tabular}
28.
56 Pemda Provinsi dan Kanwil Depag Jawa Barat,

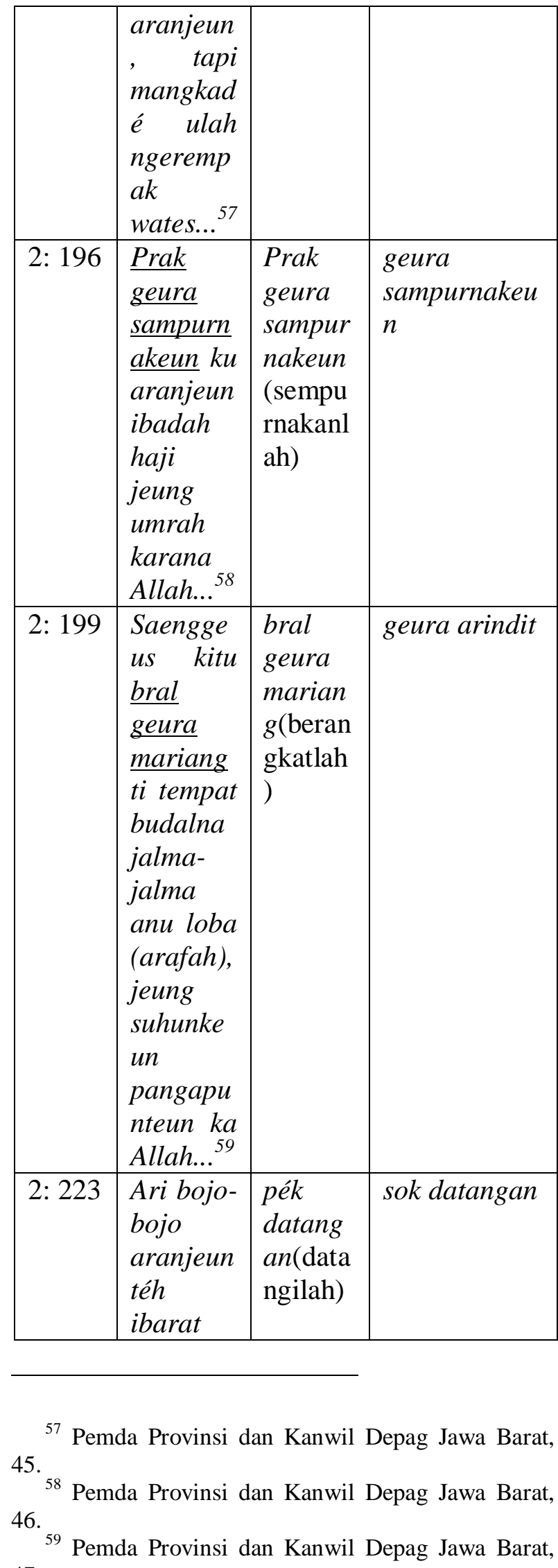
47. 


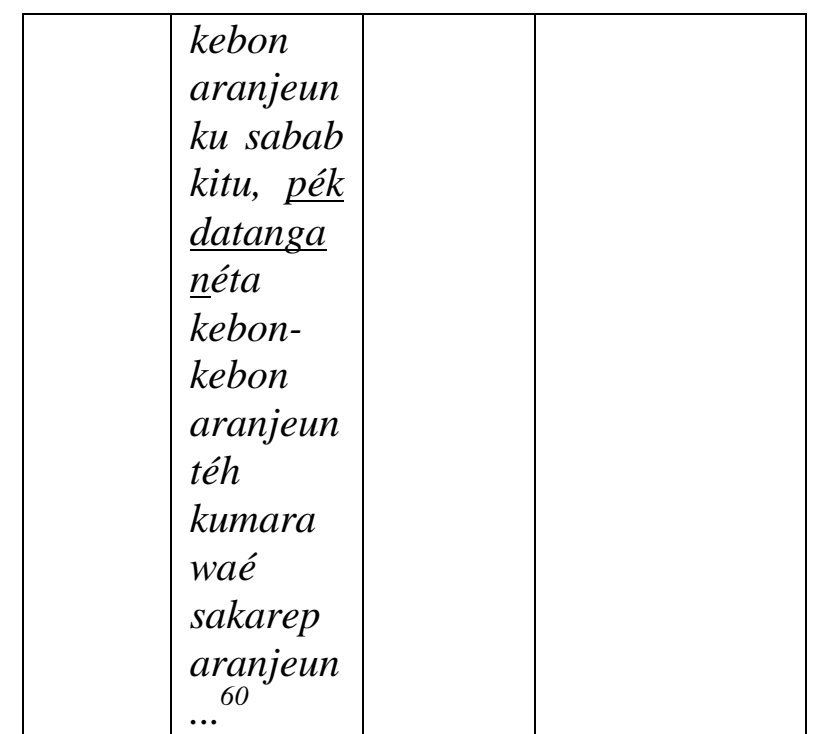

Tabel 6: Usulan Kosakatasunda Populer Dari Mahasiswa

Tabel di atas menunjukkan kosakata yang kurang dipahami dan usulan kosakatapengganti dalam bahasa Sunda populer dari mahasiswa IAT. Sebagaimana sudah dijelaskan, beberapa kosakata yang kurang dipahami itu jarang digunakan dalam percakapan sehari-hari. Sehingga bisa dipahami bila mereka kemudian mengusulkan untuk menggantinya dengan kosakataSunda populer yang biasa digunakan oleh mereka. Meskipun, beberapa kosakata yang diusulkan tersebut cenderung kamalayon (kemelayumelayuan atau berbahasa Indonesia). Kata lingsem (malu) misalnya, termasuk bahasa Sunda yang sangat halus dibanding kata $i \sin (\mathrm{malu})$. Kata terakhir lebih populer digunakan oleh mahasiswa dibanding lingsem.Begitu juga dengan kata wawales yang diusulkan diganti dengan pangbalesan(dari kata "pembalasan") dan katalimbeng dengan nyalahan ("menyalahi").

Usulan penggunaan bahasa Sunda populer yang biasa digunakan dalam percakapan sehari-hari menjadi salah satu faktor pendorong para mahasiswa untuk menggantikosakataSunda yang kurang bisa 53.

${ }^{60}$ Pemda Provinsi dan Kanwil Depag Jawa Barat, dipahami. Bahasa Sunda dalam Al-Qur'an Miwah Tarjamahna yang disusun oleh para ahli Alquran dan ahli bahasa Sunda tahun 2002 umumnya menggunakan bahasa Sunda yang baku dan sudah semakin jarang digunakan oleh generasi muda dalam kesehariannya. Sehingga bisa dipahami bila beberapa kosakata Sunda tertentu diusulkan untuk diganti dengan kosakataSunda yang lebih populer dan kekinian.Karenanya, bagi generasi milenial Sunda yang lahir sesudah tahun 1995 seperti mahasiswa IAT tersebut, terjemahan Sunda dalamAl-Qur'an Miwah Tarjamahnadianggap kurang bisa memuaskan pemahaman mereka.

Inilah yang dalam bahasa Catford disebut sebagai salah satu problem utama penerjemahan, yaitu terkait dengan ragam bahasa yang lama (arkhais), baik dalam bahasa sumber maupun bahasa sasaran. Bahasa arkhais memunculkan masalah bagaimana penerjemah harus mencari dan memilih ragam variasi bahasa yang tepat dalam bahasa sasaran. ${ }^{61}$ Pilihan variasi bahasa yang terus berkembang menjadi salah satu cara untuk menghindarkan diri dari masalah tersebut, seperti ditunjukkan dalam kasus tanggapan mahasiswa terhadap terjemahan Alquran bahasa Sunda.

\section{PENUTUP}

Pembahasan di atas menunjukkan bahwa generasi milenial Sunda yang diwakili mahasiswa IAT Fakultas Ushuluddin UIN Bandung, mayoritas kurang memahami karakteristik bahasa Sunda dalam Al-Qur'an Miwah Tarjamahna. Hal ini misalnya, tampak pada tanggapan mereka terhadap penggunaan kosakata Sunda dalam terjemahan surah $\mathrm{Al}$ $f a>t i h\} a h$ dan Al-Baqarah, terutama terkait dengan tingkatan bahasa, ungkapan idiomatik Karenanya, kajian ini merekomendasikan pentingnya pemerintah pusat dan Provinsi untuk melakukan berbagai upaya

${ }^{61}$ J. C. Catford, A Linguistic Theory of Translation, An Essay in Applied Linguistics (Oxford University Press: Oxford, 1965), 88-89. 
meningkatkan kemampuan bahasa Sunda bagi generasi milenial dan menyempurnakan kembali terjemahan Alquran bahasa Sunda agar sesuai dengan kebutuhan mereka.

\section{DAFTAR PUSTAKA}

A.Rohmana, Jajang. "Memahami Alquran Dengan Kearifan Lokal: Nuansa Budaya Sunda Dalam Tafsir Alquran Berbahasa Sunda." Journal of Qur'än and Hadìth Studies 3, no. 1 (2014): 79-99.

- "Metrical Verse as a Rule of Qur'anic Translation: Some Reflections on R.A.A. Wiranatakoesoema'sSoerat AlBaqarah(1888-1965)." Al-Jami'ah Journal of Islamic Studies 53, no. 2 (2015): 439-67. - Sejarah Tafsir Alquran Di Tatar Sunda. Bandung: Mujahid Press, 2017.

- Wawancara dengan NF, mahasiswa IAT Semester VI D (2019).

Anderson, Edmund A. n.d. "Speech Levels: The Case of Sundanese." Pragmatics International Pragmatics Association 3, no. 2 (n.d.).

Catford, J. C. A Linguistic Theory of Translation, An Essay in Applied Linguistics. Oxford University Press: Oxford, 1965.

Djajasudarma, T. Fatimah. "Kecap Anteuran Basa Sunda: Satu Kajian Semantik Dan Struktur." Universitas Indonesia, n.d.

- "Panalungtikan Basa Sunda Di Lingkungan Kodya Bandung (Program Panalungtikan Basa Sunda Rumaja." In Kongres Basa Sunda VIII, Subang, 28-30 Juni., 2005.

Dkk, Karna Yudibrata. Bagbagan Makéna Basa Sunda. Bandung: Rahmat Cijulang, 1990.

Dkk, Suwarsih Warnaen. Pandangan Hidup Orang Sunda Seperti Tercermin Dalam Tradisi Lisan Dan Sastra Sunda. Bandung: Bagian Proyek Penelitian dan Pengkajian Kebudayaan Sunda (Sundanologi) Dirjen Kebudayaan Depdikbud Bandung, 1987.

G.Zimmer, Benjamin. "Al-'Arabiyyah and
Basa Sunda: Ideologies of Tranlation and Interpretation among the Muslims of West Java." Studia Islamika, Indonesian Journal for Islamic Studies 7, no. 3 (2000): 31-65.

Hassan, Noorhaidi. "Menuju Islamisme Populer," Dalam Noorhaidi Hassan Ed., Literatur Keislaman Generasi Milenial: Transmisi, Apropriasi, Dan Kontestasi. Yogyakarta: Pascasarjana UIN Sunan Kalijaga Press, 2018.

Ikhwan, Munirul. "Fī Tahaddī Al-Dawlah: AlTarjamah Al-Tafsīriyyah Fī Muwäjahah AlKhițäb Al-Dīnī Al-Rasmī Li Al-Dawlah AlIndunīsiyyah." Journal of Qur'anic Studies 17, no. 3 (2015): 121-157.

Khädim al Haramain asy Syarīfain (Pelayan kedua Tanah Suci) Fahd ibn 'Abd al 'Azīz Al Sa'ūd, Raja Kerajaan Saudi Arabia. Alquran Dan Terjemahnya. Saudi Arabia: hädim al Haramain asy Syarīfain (Pelayan kedua Tanah Suci) Fahd ibn 'Abd al 'Azīz Al Sa'ūd, Raja Kerajaan Arab Saudi, 1990.

Lubis, Ismail. Falsifikasi Terjemahan Alquran Departemen Agama. 1990th ed. Yogyakarta: Tiara Wacana, 2001.

Moh.Zuhri. Terjemah Puitis Al-Qur'an, Kritik Ilmu Ma'ani Terhadap Al-Qur'anul Karim Bacaan Mulia Karya H.B. Jassin. Yogyakarta: Lintang-PPs IAIN Walisongo, 2012.

Nur.Ichwan, Moch. Negara, Kitab Suci, Dan Politik: Terjemah Resmi Alquran Di Indonesia, Dalam Sadur, Sejarah Terjemahan Di Indonesia Dan Malaysia, Ed. Henri Chambert-Loir,. Jakarta: KPGEFEO-Pusat Bahasa Unpad, 2009.

Pelaksana, Tim. Kosa Kata Bahasa Sunda Dalam Media Massa. Jakarta: Pusat Pembinaan dan Pengembangan Bahasa Departemen Pendidikan dan Kebudayaan, 1984.

Pemda Provinsi dan Kanwil Depag Jawa Barat. Al-Qur'an Miwah Tarjamahna Dina Basa Sunda, Bandung: Kerjasama Pemda Provinsi Jawa Barat, MUI, LPTQ, Kanwil Depag Jawa Barat. Bandung: Pemda Provinsi dan Kanwil Depag Jawa Barat, 
2002.

—. Tarjamah Al-Quräan Basa Sunda, Dikaluarkeun Ku Proyek Penerbitan AlQur'än Bahasa Sunda Jawa Barat. Bandung: Pemda Provinsi dan Kanwil Depag Jawa Barat, n.d.

Pink, Johanna. "Literal Meaning or Correct 'Aqīda? The Reflection of Theological Controversy in Indonesian Qur'an Translations." Journal of Qur'anic Studies 17, no. 3 (2015): 100-120.

Rohmana, Jajang A. "Hasil Penugasan Terjemahan Alquran Basa Sunda, Mahasiswa IAT Angkatan 2015 Semester VI Kelas A, B, C, D, E (Periode FebruariMei 2019), Prodi Ilmu Alquran Dan Tafsir, Fakultas Ushuluddin, UIN Sunan Gunung Djati Bandung." Bandung, 2019.

Romli, Usep. "Tarjamah Quran Basa Sunda Ti Jaman Ka Jaman." In Konferensi Internasional Budaya Sunda II, Gedung Merdeka, 19-22 Desember, 2011.

Rosidi, Ajip. "Mengapa Bahasa Sunda Bisa Mati?” Cupumanik 11, Juni (2004).

—. Ngabina Jeung Ngamekarkeun Kabudayaan Sunda", Dalam Ajip Rosidi Dkk., Polémik Undak Usuk Basa Sunda. Bandung: PT. Mangle Panglipur, 1987.

Satjadibrata, R. Kamus Basa Sunda. Bandung: Kiblat, 2005.

Sobarna, Cece., Djajasudarma, T.
Fatimah.,Umsari, Oyon Sofyan. Kehidupan Bahasa Sunda Di Lingkungan Remaja Kodya Bandung. Jakarta: Pusat Pembinaan dan Pengembangan Bahasa, Departemen Pendidikan dan Kebudayaan, 1997.

Sobarna, Cece. "Bahasa Sunda Sudah Di Ambang Pintu Kematiankah?" Jurnal Makara, Sosial Humaniora 11, no. 1 (n.d.). Suryadinata, Leo., Arifin, Evi Nurvidya., dan Ananta, Aris. Indonesia's Population: Ethnicity and Religion in a Changing Political Landscape. Singapore: Institute of Southeast Asian Studies, 2003.

Suryalaga, Hidayat. "Ngungkulan Bangbaluh Ngagunakeun Undak Usuk Basa." In Kempelan Makalah Kongres Basa Sunda VIII, Subang 28-30 Juni, 2005.

Tamsyah, Budi Rahayu. Kamus Undak Usuk Basa Sunda. Bandung: Geger Sunten, 2006.

Tim Pelaksana Penulisan Alquran Mushaf Sundawi. Alquran Al-Karim Mushaf Sundawi. Bandung: Tim Pelaksana Penulisan Alquran Mushaf Sundawi, 1997.

Tim Penyusun. Ringkasan Eksekutif Program Convey Indonesia. Jakarta: Enhancing the Role of Religious Education in Countering Violent Extremism in Indonesia, Pusat Pengkajian Islam dan Masyarakat (PPIM), UIN Syarif Hidayatullah Jakarta, 2018. 